phosphorylase of the major component of starch, amylopectin. He has shown, moreover, that the $Q$-enzyme from potato converts the amylose to amylopectin, and he has devised an elegant method for the separation of the two components of starch. His more recent work has been on the photochemical degradation of carbohydrates, which has opened up what is practically a new field of investigation, the main features of which appear to be an indication of the reversal of the photosynthesis of starch. $\mathrm{He}$ has served as the English editor of the international publication "Advances in Carbohydrate Chemistry".

\section{Royal Society of Medicine : Sir Henry Dale, O.M., G.B.E., F.R.S.}

THE Royal Society of Medicine elects its president annually, and he may be re-elected for a second year. The practice has been to offer the presidency in turn to a physician, a surgeon and a specialist. This year it has been the turn of the specialist, and Sir Henry Dale, the distinguished former director of the National Institute for Medical Research, and president during 1940-45 of the Royal Society, has been elected; this is the first time that a man whose chief claim to distinction has been in the field of pure science has been elected. The Royal Society of Medicine, like so many learned bodies, originated from meetings of a group of young men in London eager to discuss their work. It was founded in 1805, and its chief purpose has always been "the cultivation and promotion of physic and surgery, and all the branches of science connected with them". It received a Royal Charter in 1834. During its first century, the Society was mainly active in London, but in 1907 a number of medical societies joined forces with the Royal Medico-Chirurgical Society of London, as it was then called, to form the present well-established body, and a Supplemental Charter was given it. The Society now has some 9,000 fellows, of whom more than 1,200 are overseas ; all nationalities are represented. The Society functions through twenty-four specialized sections, which hold some two hundred meetings between them every year. Members of the Society are justly proud of its library, which has a record of great activity. Apart from the provision of books, it has been able, through a grant from the Rockefeller Foundation, to give substantial assistance in the restoration of medical libraries which had suffered through the War, by providing microfilm copies of journals now out of print.

\section{Air Photography and Archæology}

THE importance of air photography for the archæologist cannot be exaggerated. Not only does it permit accurate plotting of the visible monuments of an area to be made when detailed maps of the district are inaccurate or non-existent, but further it frequently indicates where ancient monuments now disappeared had once stood. Let us suppose a building, say, a Roman villa, once occupied an area of ground. Where the foundations had been dug the soil would have been disturbed, and, though perhaps nothing is visible now above ground, below the soil much brickwork, etc., would still occur. Corn or other crops on the field where the villa had been would grow somewhat differently as to height and density where the foundations lie, and would thus mark out as it were on a plan where they were. On the ground nothing can be seen; from the air the whole is clearly set out. Messrs. Kodak are to be congratulated on the exhibition of such photographs which has been arranged at their premises in Regent Street, London, and is open to the public until July 21. An excellent explanatory pamphlet by Dr. J. K. St. Joseph, illustrated by a number of actual air photographs, has been issued. There are also maps showing where the various sites appearing in the exhibition occur. Such well-known localities as Stonehenge and Avebury have been included.

\section{Biological Research Institute, Tihany}

THE Director-General of Unesco, Dr. Julian Huxley, during his four-day visit to Hungary as guest of the Hungarian Government, spent June 13 at the Biological Research Institute at Tihany, Lake Balaton (see Nature, 158, 456; 1946). Dr. Huxley was interested in the success of the efforts, made immediately after the cessation of fighting and during the inflation, which have resulted in a Research Institute capable of publishing, each year since 1945 , the Archiva Biologica Hungarica, containing some thirty-five papers in congress languages (mostly in English). He approved the idea which had here been followed of assembling in one Institute the greatest possible variety of biological disciplines, and showed himself keenly aware of the many advantages of such a system, especially in small countries. Dr. Huxley was interested to hear that several research workers were to go to the Institute for a period. Two places are reserved for invited Russian biologists ; two English men of science are going for the summer and autumn and two Finnish biologists are also expected.

\section{Exchange of War-time Periodicals with Germany}

EFForts are still being made by the Foreign Office to make possible the exchange in bulk of periodicals issued during the Second World War by British learned societies, universities, and other institutions with those published by similar bodies in Germany. These efforts are more likely to be effective if information concerning the numbers of publications involved can be supplied. Interested librarians are accordingly asked to notify either the Director of the Association of Special Libraries and Information Bureaux, 52 Bloomsbury Street, London, W.C.1, or the Secretary of the Library Association, if they have not already done so: $(a)$ of the total number of volumes or parts of periodicals issued during the War and held by them for exchange with German institutions, and $(b)$ of the numbers which they should receive in return, indicating clearly whether it is known that these German publications are available for exchange purposes. The returns should be headed : "German exchange". It should be understood that the information asked for relates only to the war-time accumulation of periodicals for exchange. Future exchanges must be arranged by institutions in the two countries privately.

\section{Benjamin Franklin as Printer and Publisher}

VoL. 92, No. 2 of the Proceedings of the American Philosophical Society (1948) is devoted to studies of historical documents in the library of the Society at Philadelphia. Chief among these is a paper by W. E. Lingelbach on new source material regarding Benjamin Franklin's activities as printer and publisher both during the first half of his life and in his later years. Much of the material relates to his interests in Philadelphia during 1728-66, the most interesting being concerned with his printing activities in Passy. This latter includes a unique collection of more than 
four hundred brass stencils, apparently used by Franklin in the study and designing of type, as well as inventories of fonts cast at Passy and of type and other printing materials purchased from the leading English, French and possibly Dutch type-founders. Other articles in this number include Prof. G. Chinard's study of Franklin as negotiator, December 1777, Prof. P. A. W. Wallace's appreciation of H. E. Muhlenberg's work as botanist, Prof. T. D. Cope's note "Collecting Some Material about Charles Mason and Jeremiah Dixon", the astronomers and geodetic surveyors, and Prof. I. J. Cox's account of the Freeman Red River Expedition of 1806.

\section{Establishment of Hardwoods in Britain}

MANY will welcome the small Forestry Commission pamphlet No. 2 of the Forest Operations Series (who invents these cumbersome titles?) on the "Establishment of Hardwoods" (London: H.M. Stationery Office. $9 d$. net). The small area of 35,000 acres only was afforested or replanted in Britain with various hardwoods during the first twenty-five years of the Forestry Commission. A bulletin recording the information so far gathered on the subject of sowing and planting to form the new plantations was in the press just before the outbreak of war, but was destroyed during the bombing of London. The present one has been prepared from a report of $\mathrm{Mr}$. A. H. Popert, acting conservator in the south-west of England, as a result of a tour of the Commission's hardwood plantations. It is perfectly well known that the raising and tending of young hardwood crops, save in exceptionally favourable circumstances of habitat, are more difficult and call for more experience than is required for conifers. The bulletin gives notes on the chief timber species-oak, beech, ash, sycamore, sweet chestnut, birch and alder. It also deals with the treatment of coppice woods and devastated woodlands ; on these latter subjects, some who have lived with and studied coppice areas may differ from the views contained in the paper. As a result of war-time and present-day fellings of the fine hardwoods, it is noted that the "Establishment of broadleaved trees is likely to assume increasing importance in British Forestry".

\section{"Not poppy, nor mandragora ...."}

"An Index of Modern Remedies", by William Mair, has, since it was first published in 1941 , been useful to the medical and pharmaceutical professions, to whom alone it is issued. The appearance of a new edition (Fourth Series, 1948. Scottish Chemist, 240 Albert Drive, Pollokshields, Glasgow, S.1 ; and from Messrs. H. K. Lewis and Co., Ltd., 136 Gower Street, London. 3s.) will therefore be welcomed. This new edition contains, as well as a few recently coined names of remedies, a valuable article on the 1948 edition of the British Pharmacopœia, with lists of the 250 new admissions to this publication and of the omissions from it. There is also a useful list of costly and essential drugs now exempted from the purchase tax. As Mr. Mair rightly says in his introductory note, no physician or pharmacist can nowadays be familiar with the names, composition and action of all the pharmaceutical preparations on the market, and he has set out to give this information in a handy and well-indexed form. He also gives, by means of a key, the names and addresses of manu. facturing chemists and the preparations which they make. Using this book, one realizes how many names some drugs nowadays have, the changes these names have undergone and how different they may be in different countries. Pentothal, for example, is now thiopentone soluble B.P. and U.S.P., and aminacrine hydrochloride B.P. used to be, and no doubt still is in some quarters, acramine, monacrin or acramine yellow. The maze of names given to the antimalarial drugs and to the sulphonamides and their derivatives are here sorted out, and a short supplement lists special injection solutions for parenteral therapy. More than half the book is devoted to a classification of various remedies according to their mode of action. In this section the statement that phenothiazine is an anthelmintic of low toxicity needs modification. As Prof. J. H. Gaddum says in his foreword, this book is a valuable guide and provides information not easily obtained elsewhere, even in more expensive books.

\section{Pfund Issue of the Journal of the Optical Society of America}

The October 1947 issue of the Journal of the Optical Society of America is the largest issue of the journal ever to be published and was specially called the "Pfund Issue". It consists of articles written by Prof. A. H. Pfund's former students and colleagues and is a tribute to him on his retirement from active teaching at the Johns Hopkins University. An advance copy of this issue, together with a 'scrapbook' containing the letters which accompanied the manuscripts of the articles when they were submitted for publication, was presented to Prof. Pfund at the dinner held during the thirty-second annual meeting of the Society in October last. A photograph of Prof. Pfund is on the opening page, and the first of the twenty-three articles in the issue is by Prof. R. W. Wood, who writes on "The Use of Echelette Gratings in High Orders". Two of the articles are actually by Prof. Pfund himself and co-workers, but he was unaware that his colleagues had submitted the papers for a special issue of the Journal. They deal with selective infra-red gas analysers and with optical scattering by dielectric powders. The other articles include: a historical note on the rate of a moving clock by H. E. Ives; a spark light-source of short duration by J. W. Beams and others; an optical study of acoustic fields near diffraction edges by J. C. Hubbard and others; and practical methods of making and using multilayer filters by Mary Banning.

\section{Hot-wire Vacuum Switches}

Sunvic Controls, Lrd., 10 Essex Street, Strand, London, W.C.2, manufacturers of vacuum switches, temperature control and associated equipment, have recently issued a 16-page illustrated pamphlet describing their hot-wire vacuum switches. The Sunvic hot-wire vacuum switch is contained within an evacuated glass tube not much larger than an ordinary radio valve, and is a non-arcing electric relay, the operation of which depends on the fact that when an electric current is interrupted by the separation of two surfaces in a vacuum no arc is formed. The movement necessary to close or open the switch is quite small and is provided by the thermal expansion of a special steel wire through which a control current of some $25-60 \mathrm{~m}$.amp. is passed. The switch contacts are tungsten and are normally held apart against a compressed spring, which is released by the expansion of the hot wire. The operating characteristics of many different forms of hot-wire vacuum switches with various time delays, 